\title{
JURISDICTION STRIPPING, CONSTITUTIONAL SUPREMACY, AND THE IMPLICATIONS OF EX PARTE YOUNG
}

\author{
THEODORE J. WEIMAN ${ }^{\dagger}$
}

On July 22, 2004, ${ }^{1}$ the House of Representatives passed the Marriage Protection Act of 2004, a bill that would strip the federal courts of jurisdiction over cases challenging the constitutionality of the 1996 Defense of Marriage Act. ${ }^{2}$ Two months later, the House passed a similar bill that would curtail federal court jurisdiction for challenges to the constitutionality of the Pledge of Allegiance or its recitation. ${ }^{3}$ Though perhaps unlikely to pass the Senate, the bills represent an attempt by Congress to avoid potential federal court determination of issues involving important areas of constitutional law ${ }^{4}$ with the hope of

${ }^{\dagger}$ B.A. 2000, The University of Texas at Austin; J.D. Candidate 2006, University of Pennsylvania Law School. I would like to thank the scholars whose work I have cited in this Comment for their thoughtful and well-researched work. I have learned a great deal from them throughout this process, and I have been constantly amazed and inspired by the depth of their analysis. I am also grateful to my parents, Liz and Larry, and my sister, Julie, for their constant support, encouragement, and inspiration. Finally, I thank the editors of this Law Review for their careful work and helpful comments. All errors and opinions are my own.

${ }^{1}$ Earlier in the year, a member of the House proposed a much broader bill that would remove federal court jurisdiction over claims involving same-sex marriage, the right to privacy, and state and local restrictions of free exercise or establishment of religion, but this bill is still in committee. See H.R. 3893, 108th Cong. (2004).

${ }^{2}$ H.R. 3313, 108th Cong. (2004) ("No court created by Act of Congress shall have any jurisdiction, and the Supreme Court shall have no appellate jurisdiction, to hear or decide any question pertaining to the interpretation of, or the validity under the Constitution of, section 1738C or this section.”). The Defense of Marriage Act dictated that states were not required to give effect to same-sex marriages recognized by other states. See Defense of Marriage Act, Pub. L. No. 104-199, § 2(a), 110 Stat. 2419 (1996) (codified at 28 U.S.C. $\$ 1738 \mathrm{C}$ (2004)).

${ }^{3}$ Pledge Protection Act of 2004, H.R. 2028, 108th Cong. (2004) ("No court created by Act of Congress shall have any jurisdiction, and the Supreme Court shall have no appellate jurisdiction, to hear or decide any question pertaining to the interpretation of, or the validity under the Constitution of, the Pledge of Allegiance ... or its recitation.").

${ }^{4}$ These proposals are similar to past attempts to strip federal court jurisdiction over substantive constitutional issues, in which Congress sought to reverse existing Supreme Court decisions. See ERWIN CHEMERINSKY, FEDERAL JURISDICTION § 3.1, at 172 (4th ed. 2003) ("The obvious purpose of most jurisdiction stripping bills is to achieve a change in the substantive law by a procedural device."); Lawrence Gene Sager, The Su- 
obtaining particular substantive results in state courts. If the acts become law, the constitutional issues over which state courts would have the last word include the scope of the Full Faith and Credit Clause of Article $\mathrm{IV}^{5}$ and the Equal Protection and Due Process Clauses of the Fourteenth Amendment, ${ }^{6}$ in cases affected by the Marriage Protection Act, as well as the Establishment Clause of the First Amendment, ${ }^{7}$ in cases affected by the Pledge Protection Act. Jurisdiction-stripping proposals with similar purposes have been advanced in Congress since as early as $1830,{ }^{8}$ though such attempts have rarely been enacted into

preme Court, 1980 Term-Foreword: Constitutional Limitations on Congress'Authority to Regulate the Jurisdiction of the Federal Courts, 95 HARV. L. REV. 17, 18 (1981) ("The sponsors of these bills ... aim to undo the mischief that the federal courts have wrought through erroneous interpretations of the Constitution."); Laurence H. Tribe, Jurisdictional Gerrymandering: Zoning Disfavored Rights Out of the Federal Courts, 16 HARV. C.R.-C.L. L. REV. 129, 129-30 (1981) (noting that the proposals represent an attempt at a "de facto reversal, by means far less burdensome than those required for a constitutional amendment, of several highly controversial Supreme Court rulings dealing with matters such as abortion, school prayer, and busing" (footnote omitted)).

${ }^{5}$ See U.S. CONST. art. IV, $\$ 1$ ("Full Faith and Credit shall be given in each State to the public Acts, Records, and judicial Proceedings of every other State; And the Congress may by general Laws prescribe the Manner in which such Acts, Records and Proceedings shall be proved, and the Effect thereof."); Andrew Koppelman, Dumb and DOMA: Why the Defense of Marriage Act Is Unconstitutional, 83 IOWA L. REV. 1, 10-24 (1997) (analyzing the constitutionality of the Defense of Marriage Act under the Full Faith and Credit Clause).

${ }^{6}$ See U.S. CONST. amend. XIV, $§ 1$ ("No State shall ... deprive any person of life, liberty, or property, without due process of law; nor deny to any person within its jurisdiction the equal protection of the laws."); Note, Litigating the Defense of Marriage Act: The Next Battleground for Same-Sex Marriage, 117 HARV. L. REV. 2684, 2688 (2004) (arguing that the Defense of Marriage Act "violates principles of equal protection and due process").

${ }^{7} \mathrm{See}$ U.S. CONST. amend. I ("Congress shall make no law respecting an establishment of religion ....”); Newdow v. U.S. Congress, 328 F.3d 466, 490 (9th Cir. 2003) (holding that a "school district's policy and practice of teacher-led recitation of the Pledge, with the inclusion of the added words 'under God,' violates the Establishment Clause"), rev'd on other grounds, Elk Grove Unified Sch. Dist. v. Newdow, 124 S.Ct. 2301, 2312 (2004) (holding that the plaintiff lacked standing to bring the suit in federal court without ruling on the merits of the constitutional claim).

${ }^{8}$ See CHEMERINSKY, supra note 4, § 3.1, at 171 (“"[B]etween 1953 and 1968, over sixty bills were introduced into Congress to restrict federal court jurisdiction over particular topics."); Robert N. Clinton, A Mandatory View of Federal Court Jurisdiction: A Guided Quest for the Original Understanding of Article III, 132 U. PA. L. REV. 741, 744-45 \& nn.5-7 (1984) (discussing prior jurisdiction-stripping proposals); Gerald Gunther, Congressional Power to Curtail Federal Court Jurisdiction: An Opinionated Guide to the Ongoing Debate, 36 STAN. L. REV. 895, 895 (1984) ("In 1981 and 1982 alone, thirty jurisdictionstripping bills were introduced in Congress, some eliciting extensive committee hearings. Most of the proposals stem from dissatisfaction with Supreme Court decisions ...." (footnote omitted)); Leonard G. Ratner, Congressional Power over the Appellate Jurisdiction of the Supreme Court, 109 U. PA. L. REV. 157, 159 (1960) (“[A]s early as 
law and have never completely eliminated Supreme Court review of a particular substantive area of law. ${ }^{9}$ However, because of the importance of the constitutional interests threatened by these attempts, and the prospect that Congress might someday enact such a law, ${ }^{10}$ these proposals have stimulated an intense academic debate over the extent to which Congress may curtail the jurisdiction of federal courts, taking into account textual, doctrinal, historical, and policy considerations. ${ }^{11}$

These discussions have usually focused on isolated analyses of clauses in Article III of the Constitution, ${ }^{12}$ and many theorists approach jurisdiction stripping primarily (if not solely) as a separationof-powers issue. ${ }^{13}$ Besides proffering arguments based in the Constitution's text, those who believe that Congress has broad jurisdictionstripping powers often justify their interpretations by contending that such powers serve as a majoritarian check on a countermajoritarian judiciary. ${ }^{14}$ Opponents of jurisdiction-stripping proposals respond

1830 congressional legislation was introduced which proposed to eliminate the Supreme Court's appellate jurisdiction over state court decisions ....").

${ }^{9}$ See CHEMERINSKY, supra note 4 , at $\$ 3.1$, at 176-77 ("Congress rarely has attempted such jurisdiction stripping [for substantive topics] - and never in a manner that has been interpreted as precluding all Supreme Court review ...."); cf. Sager, supra note 4, at 19 ("The judiciary has never had the occasion to rule decisively on such incursions into federal jurisdiction ....").

${ }^{10}$ See Akhil Reed Amar, The Two-Tiered Structure of the Judiciary Act of 1789, 138 U. PA. L. REV. 1499, 1500-01 (1990) (noting the importance of considering the jurisdiction-stripping issue even when there is no real, current threat of such a law being enacted).

${ }^{11}$ See Clinton, supra note 8, at 748 (noting that, while some academic literature has focused on the history of Article III, "the bulk of the writing in this field has been devoted to more current doctrinal and policy considerations").

${ }^{12}$ See id. at 749 ("The debates over congressional power to curtail federal court jurisdiction generally have centered around the interpretation of particular clauses in article III taken in isolation.”).

${ }^{13}$ See Louise Weinberg, The Article III Box: The Power of "Congress" to Attack the "Jurisdiction" of "Federal Courts," 78 TEX. L. REv. 1405, 1413 (2000) (finding that federalcourt theorists traditionally treat jurisdiction stripping as a separation-of-powers issue between the legislative and judicial branches of government). See, e.g., CHEMERInSkY, supra note 4, § 3.1, at 175 ("The scope of Congress's power to define federal court jurisdiction focuses attention on separation of powers and the allocation of power among the branches of the federal government."); Amar, supra note 10, at 1500 ("[T] he basic separation of powers issue ... [is] how much power to restrict federal jurisdiction does the Constitution give Congress?"); Sager, supra note 4, at 17 (stating that Congressional jurisdiction-stripping bills constitute "one of the most serious threats ever directed toward the independent authority of the federal judiciary").

${ }^{14}$ See CHEMERINSKY, supra note $4, \S 3.2$, at 187 ("Supporters of proposals to limit Supreme Court jurisdiction under the 'exceptions and regulations' clause argue that such congressional power is an essential democratic check on the power of an unelected judiciary."); see also Michael Wells, Congress's Paramount Role in Setting the 
with their own textual arguments, supported by structural arguments that, by restricting federal court jurisdiction, Congress would be impermissibly weakening judicial independence and contravening the judiciary's proper role in our tripartite system of federal government - that of interpreting the Constitution and protecting constitutional rights. ${ }^{15}$ Arguments on both sides are pertinent and well founded, making the separation-of-powers perspective on the jurisdiction-stripping debate compelling.

Yet jurisdiction-stripping laws would not, ipso facto, reverse $\mathrm{Su}-$ preme Court decisions or dictate a required judicial construction of substantive law; ${ }^{16}$ rather, state courts would remain to resolve the particular claims affected. ${ }^{17}$ As a result, Congress's constitutional power to limit federal court jurisdiction could be viewed by proponents not only as a majoritarian check on the judiciary, but also as a function of our federalist system. That is, such power allows Congress to delegate judicial resolution of particular issues to the courts of the states rather than those of the federal government. ${ }^{18}$ By complement, congres-

Scope of Federal Jurisdiction, 85 Nw. U. L. REv. 465, 467 (1991) ("Since the members of Congress are elected by state and local constituencies, they are responsive to state and local concerns and provide a necessary check on the power of the unelected and tenured federal judiciary.").

${ }^{15}$ See Chemerinsky, supra note $4, \S 3.2$, at 188 (“[O]pponents [of jurisdictionstripping proposals] argue that the Constitution and the Court are intentionally antimajoritarian and it is undesirable to create a majoritarian check on the process of constitutional interpretation.”).

${ }^{16}$ At least, the class of bills analyzed here would not; they would only curtail federal court jurisdiction over substantive areas of law. Laws that would attempt to actually reverse Supreme Court decisions or dictate federal court rulings would arguably violate separation of powers even more directly.

${ }^{17}$ See Richard H. Fallon, Jr., The Ideologies of Federal Courts Law, 74 VA. L. REV. 1141, 1215 (1988) ("If Congress withdraws lower federal court jurisdiction over a class of cases, the normal result will be that adjudication must occur in state court."); Weinberg, supra note 13, at 1410, 1411 (stating that "as long as there is access to state courts for enforcement of federally-created rights, much of our concern about legislation denying access to federal courts must inevitably seem overblown" and that " $[\mathrm{u}]$ nder the Supremacy Clause the states have an obligation to try federal cases"); cf. Henry M. Hart, Jr., The Power of Congress to Limit the Jurisdiction of Federal Courts: An Exercise in Dialectic, 66 HARV. L. REV. 1362, 1401 (1953) ("In the scheme of the Constitution, [state courts] are the primary guarantors of constitutional rights ...."). In cases over which the state courts have no judicial power, such as suits against federal officials or habeas petitions for prisoners in federal custody, due process concerns likely prevent curtailment of federal court jurisdiction because no court would remain to hear the claim. Weinberg, supra note 13, at 1423 ("Congress cannot strip federal courts of power [in cases in which federal jurisdiction is exclusive] without raising the issue of due process ... because ... it eliminates jurisdiction in both sets of courts.").

is See Fallon, supra note 17, at 1215-16 (arguing that jurisdiction stripping implicates the relative competencies of the federal and state courts to hear federal issues). 
sional curtailment of federal court jurisdiction could be viewed by opponents as violative of not only the proper separation of powers in our federal government, but also nationalist principles of federal supremacy that would militate against allowing states to be the final arbiters of federal—and in particular, constitutional-law.

From this perspective, the jurisdiction-stripping debate implicates the same competing concerns of federalism and nationalism that arise in other conflicts of constitutional law, notably the Supreme Court's sovereign immunity jurisprudence. While the Court has recognized a constitutionally protected sovereign immunity for states based on principles of federalism and state dignity, ${ }^{19}$ it has tempered the effect of that interpretation with a counteracting nationalist strain of law under Ex parte Young. ${ }^{20}$ This strain requires the availability of a federal forum in certain cases against state officials in order to uphold the Supremacy Clause of the Constitution. ${ }^{21}$

There is a striking similarity between the issues involved in analyzing sovereign immunity and jurisdiction stripping: in both cases, a federal forum for the vindication of federal or constitutional rights may be threatened; both bars are somewhat jurisdictional; and the sides of each debate generally correspond to ideologies of modern federalism and nationalism. ${ }^{22}$ Further, many suits that would be barred in federal court if Congress were to restrict jurisdiction over a substantive issue are suits that are already partially barred by current sovereign immunity doctrine but given life under the Young exception. Plaintiffs who would normally be able to sue state officials in federal court for alleged constitutional violations under the Young exception $^{23}$ would lose that method of recourse in the areas covered by

${ }^{19}$ See Alden v. Maine, 527 U.S. 706, 715 (1999) ("The generation that designed and adopted our federal system considered immunity from private suits central to sovereign dignity.").

209 U.S. 123 (1908).

${ }^{21}$ See Fallon, supra note 17, at 1145 (noting that a nationalist model of judicial federalism appears in Supreme Court cases which argue that "state sovereignty interests must yield to the vindication of federal rights and that, because state courts should not be presumed as competent as federal courts to enforce constitutional liberties, rights to have federal issues adjudicated in a federal forum should be construed broadly" (footnote omitted)); infra notes 106-10 and accompanying text.

${ }^{22}$ See Fallon, supra note 17, at 1145 (arguing that ideologies of nationalism and federalism explain, in part, the opposing positions in the debates over " $[\mathrm{w}]$ hich suits against the states are excluded from the federal judicial power by the eleventh amendment" and whether "Congress [must] vest some or all of "the judicial power of the United States' in either lower federal courts or the Supreme Court").

${ }^{23}$ See infra notes 98-99 and accompanying text. 
the jurisdiction-stripping law, even though the same pressing concerns that underlie the Young doctrine would remain. The similarities between the interests implicated by these two areas of constitutional debate make an analysis of sovereign immunity jurisprudence relevant in a discussion of jurisdiction stripping, ${ }^{24}$ and may weigh in favor of recognizing a constitutional limitation on Congress's jurisdictionstripping power based in the Supremacy Clause, much as Young serves a similar purpose for circumventing states' sovereign immunity.

Given the Supreme Court's current federalist momentum, it is possible that the Court might approach a jurisdiction-stripping law largely as a question of judicial federalism-the proper role of state and federal courts within the dual-court system ${ }^{25}$-and interpret Article III as allowing Congress essentially to divert substantive issues to state courts. The Supreme Court has consistently upheld the principle that our "system of federalism" is one "in which the state courts share responsibility for the application and enforcement of federal law"; ${ }^{26}$ if the Court looks at a jurisdiction-stripping law from this perspective-viewing state courts as competent and appropriate to hear cases involving federal questions-the Court is unlikely to find within Article III any strong limits on Congress's power to restrict federal court jurisdiction. ${ }^{27}$ Considering the increased prominence of federalist principles under the current Court and the implications this may have for Congress's power to restrict federal court jurisdiction, a new examination of jurisdiction stripping from a federalist perspective, tempered by its counteracting nationalist principle, is appropriate.

${ }^{24}$ See Weinberg, supra note 13, at 1430 (analyzing sovereign immunity cases and concluding that "cases in which the Court has addressed the availability of a judicial forum are obviously relevant to an examination of Congress's court-stripping powers").

${ }^{25}$ See Fallon, supra note 17, at 1143-44 (identifying the Supreme Court's dominant model of judicial federalism as the federalist model and viewing "state courts, which are presumed to be as fair and competent as federal courts, . . a the ultimate guarantors of constitutional rights"); cf. Weinberg, supra note 13, at 1417-18, 1420-22 (arguing that jurisdiction stripping might be undertaken for federalism or procedural concerns, or even a version of "tort reform" applying to constitutional issues). Professor Fallon defines judicial federalism as encompassing "virtually all questions involving the respective competences of state and federal courts to adjudicate issues and award remedies in cases of joint state and federal interest." Fallon, supra note 17, at 1142 n.1.

${ }^{26}$ Howlett v. Rose, 496 U.S. 356, 372-73 (1990).

${ }^{27}$ Cf. Weinberg, supra note 13, at 1407 ("[B] ecause the Supreme Court has been the more important actor in stripping the lower courts of power, it is unlikely that the current Court could or would find strong constitutional limits on the power of Congress to do so."). 


\section{Congressional Power to CuRTAIL FEDERAL COURT JURISDICTION}

\section{A. The Traditional Theory of Jurisdiction Stripping}

The debate over jurisdiction stripping has traditionally isolated two areas of federal jurisdiction for analysis: the jurisdiction (both original and appellate) of lower federal courts and the Supreme Court's appellate jurisdiction. ${ }^{28}$

The details of federal court jurisdiction are sketched in Article III of the Constitution, and the clauses therein have appropriately drawn the lion's share of academic discussion. ${ }^{29}$ Section 1 states that " $[\mathrm{t}]$ he judicial Power of the United States, shall be vested in one supreme Court, and in such inferior Courts as the Congress may from time to time ordain and establish," institutes life tenure for federal judges, and prohibits diminution of their pay while in office. ${ }^{30}$ The scope of this "judicial Power" is described in the first clause of Section 2, which states that the power "shall extend" to the cases and controversies specified within the clause, including "all Cases, in Law and Equity, arising under this Constitution, the Laws of the United States, and Treaties made, or which shall be made, under their Authority." ${ }^{31}$ The second clause of Section 2 limits the Supreme Court's original juris-

\footnotetext{
${ }^{28}$ A third area, involving Congress's power to eliminate the jurisdiction of both federal and state courts to hear a particular case, presents an interesting academic issue, see generally Weinberg, supra note 13 (discussing the power of Congress to deny access to all courts, federal and state), but it is generally understood that due process concerns prevent Congress from rendering all courts unavailable to hear a claim. See CHEMERINSKY, supra note 4 , § 3.2, at 201; Weinberg, supra note 13, at 1423 . It is also well established that Congress possesses no ability to expand or contract the original jurisdiction of the Supreme Court. See Marbury v. Madison, 5 U.S. (1 Cranch) 137, 174-75 (1803); Sager, supra note 4, at 24. Article III limits this jurisdiction to "all Cases affecting Ambassadors, other public Ministers and Consuls, and those in which a State shall be Party." U.S. CONST. art. III, § 2, cl. 2. Pertinent here, then, is the original and appellate jurisdiction of the lower federal courts and the appellate, but not original, jurisdiction of the Supreme Court.

${ }^{29}$ See supra note 12.

${ }^{30}$ U.S. CONST. art. III, $\$ 1$.

${ }^{31} I d$. $\$ 2, \mathrm{cl}$. 1. This clause also extends the judicial power: to all Cases affecting Ambassadors, other public Ministers and Consuls; - to all Cases of admiralty and maritime Jurisdiction; - to Controversies to which the United States shall be a Party; - to Controversies between two or more States; - between a State and Citizens of another State; - between Citizens of different States; - between Citizens of the same State claiming Lands under Grants of different States, and between a State, or the Citizens thereof, and foreign States, Citizens or Subjects.
} 
diction to cases involving ambassadors, public ministers and consuls, and those in which a state is a party. ${ }^{32}$ The clause also provides that "[i]n all the other Cases before mentioned, the supreme Court shall have appellate Jurisdiction, both as to Law and Fact, with such Exceptions, and under such Regulations as the Congress shall make."33

The traditional interpretation of Article III, advanced by those who support extensive congressional ability to limit jurisdiction, is that the maximum possible extent of federal court power is represented by the "judicial Power" laid out in Section 2, Clause 1, and Congress may distribute that power as it sees fit, even if that means removing jurisdiction altogether ${ }^{34}$ (with the exception of the Supreme Court's original jurisdiction).$^{35}$ Because Congress is not required to establish the lower federal courts at all, but rather "may from time to time ordain and establish" " them, Congress can define the jurisdiction of those courts however it wishes. ${ }^{37}$

The textual basis for Congress's ability to restrict Supreme Court appellate jurisdiction is perhaps even more explicit, as the Constitution grants such jurisdiction to the Court "with such Exceptions, and under such Regulations as the Congress shall make." 38 Those who believe Congress has broad jurisdiction-stripping powers view this as an explicit, unqualified grant of congressional power to eliminate $\mathrm{Su}-$

Id. $\S 2$, cl. 2.

${ }^{33} I d$.

${ }^{34}$ See Daniel J. Meltzer, The History and Structure of Article III, 138 U. PA. L. REV. 1569, 1569 (1990) (“[T] he traditional view of article III [is] that Congress . . . may deprive the lower federal courts, the Supreme Court, or all federal courts of jurisdiction over any cases within the federal judicial power, excepting only those few that fall within the Supreme Court's original jurisdiction."); Julian Velasco, Congressional Control over Federal Court Jurisdiction: A Defense of the Traditional View, 46 CATH. U. L. REV. 671, 674-78 (1997) (discussing the traditional viewpoint).

${ }^{35}$ See supra note 28 and accompanying text.

${ }^{36}$ U.S. CONST. art. III, § 1.

37 See Hart, supra note 17, at 1363-64 ("Congress seems to have plenary power to limit federal jurisdiction when the consequence is merely to force proceedings to be brought, if at all, in a state court."). In upholding congressional restriction of diversity jurisdiction, the Supreme Court has agreed that, "having a right to prescribe, Congress may withhold from any court of its creation jurisdiction of any of the enumerated controversies. Courts created by statute can have no jurisdiction but such as the statute confers." Sheldon v. Sill, 49 U.S. (8 How.) 440, 448 (1850); see also CHEMERINSKY, supra note $4, \S 3.3$, at 192-96 (reviewing this and other Supreme Court opinions that approve of congressional restriction of lower court jurisdiction, as well as the responses of opponents of jurisdiction stripping).

${ }^{38}$ See U.S. CONST. art. III, § 2 . 
preme Court appellate jurisdiction $^{39}$ and allow no appeal from lower federal courts or state supreme courts to the Supreme Court of the United States. ${ }^{40}$

Proponents of this interpretation support their textual argument by contending that such congressional control is necessary to provide a majoritarian check on a countermajoritarian judiciary. ${ }^{41}$ Without this control, the argument goes, the democratically elected representatives of the people would be left little power to rein in the excesses of unelected judges, which is antithetical to the majoritarian principles upon which our republic is built. Congressional restriction of federal court jurisdiction also allows the state courts to serve a legitimate function in the federalist system, in that they are fully competent to decide issues of federal or constitutional law. ${ }^{42}$

\section{B. Arguments in Favor of Limiting Congressional Power over Jurisdiction}

Persuasive arguments have been made, however, to counter the traditional interpretation in an attempt to prevent Congress from curtailing federal court jurisdiction. ${ }^{43}$ One set of arguments looks to the wording and structure of Article III to find mandatory federal court jurisdiction beyond the Supreme Court's original jurisdiction. Justice Story, in dictum in Martin v. Hunter's Lessee, first pointed out that the text of Article III distinguished between two different categories of jurisdiction and argued that Congress was obligated to establish lower

${ }^{39}$ There is no similar exceptions-and-regulations clause in the Constitution for the Supreme Court's original jurisdiction. See Meltzer, supra note 34, at 1597 ("Article III expressly made the appellate jurisdiction subject to Congress's power to make exceptions, but gives no such power to limit the original jurisdiction.”).

${ }^{40}$ See CHEmerinsky, supra note $4, \S 3.3$, at 177 ("The claim is that the unambiguous language of Article III authorizes Congress to create exceptions to the Supreme Court's jurisdiction and that such exceptions include the ability to preclude review of particular topics, such as abortion or school prayer cases.”); Martin H. Redish, Text, Structure, and Common Sense in the Interpretation of Article III, 138 U. PA. L. REV. 1633, 1638 (1990) (stating that Article III "vests an unencumbered and unconditional authority in Congress to make exceptions to the Supreme Court's appellate jurisdiction").

${ }^{41}$ See supra note 14.

${ }^{42}$ Cf. Martin H. Redish, Constitutional Limitations on Congressional Power to Control Federal Jurisdiction: A Reaction to Professor Sager, 77 Nw. U. L. REV. 143, 155 (1982) ("The state courts have, since the nation's beginning, been deemed both fully capable of and obligated (under the supremacy clause) to enforce federal law, including the Constitution." (footnote omitted)).

${ }^{43}$ See Velasco, supra note 34, at 678-96 (discussing comprehensively, though rejecting, arguments to limit congressional power over federal court jurisdiction). 
federal courts "to vest all that jurisdiction which, under the constitution is exclusively vested in the United States, and of which the supreme court cannot take original cognisance." ${ }^{44}$ Several scholars have since have launched other arguments for mandatory views of Article III jurisdiction. Some contend, like Justice Story, that the establishment of the lower federal courts is required, despite the language of Article III which is seemingly permissive, rather than mandatory, on this point. ${ }^{45}$ Others argue that, although lower federal courts are not required, all cases and controversies included under the judicial power in Article III must ultimately be heard by some federal court, and thus if there were no inferior federal courts, the claims would need to be heard by the Supreme Court on appeal. ${ }^{46}$

A significant problem with these mandatory views of federal jurisdiction is that they are weakened by history, particularly the failure of the Judiciary Act of 1789 to fully vest the Article III judicial power in federal courts. ${ }^{47}$ In fact, significant jurisdictional exceptions remained in place for a century or more. Federal courts had no general federalquestion jurisdiction until $1875^{48}$ and under section 25 of the Act, appeals from state supreme courts to the Supreme Court of the United States were only available when the state court ruled against a federal

${ }^{44} 14$ U.S. (1 Wheat.) 304, 331; see Amar, supra note 10, at 1501-02 (discussing Justice Story's argument). Professor Amar isolates three premises to Story's argument: first, that the judicial power of the United States must be entirely vested in some federal court in either original or appellate form; second, that some cases, including federal criminal prosecutions, could only be heard by federal courts; and finally, that the Supreme Court's original jurisdiction could not be expanded to include all such cases. See Akhil Reed Amar, A Neo-Federalist View of Article III: Separating the Two Tiers of Federal Jurisdiction, 65 B.U. L. REV. 205, 211-12 (1985) (analyzing the three premises).

${ }^{45}$ See, e.g., Theodore Eisenberg, Congressional Authority to Restrict Lower Federal Court Jurisdiction, 83 Yale L.J. 498, 505-06, 508-09, 513 (1974) (arguing that the discretionary nature of Supreme Court review, combined with the founders' belief that a federal court should ultimately hear every claim, required the existence of lower federal courts); Sager, supra note 4, at 61-65 (arguing that once the lower federal courts are created by Congress, the life tenure and salary provisions of Article III require that they cannot be altered).

${ }^{46}$ See Clinton, supra note 8, at 749-50, 776-78, 796 (arguing that the use of the mandatory word "shall" in Article III requires that the entire Article III judicial power be vested in some federal court, and that Congress's ability to regulate and make exceptions to the Supreme Court's power only allows them to allocate jurisdiction between the various federal courts).

${ }^{47}$ See Amar, supra note 10, at 1519-21 (discussing the problems with Professor Clinton's mandatory view of federal court jurisdiction with respect to the 1789 Judiciary Act).

${ }^{48}$ Act of Mar. 3, 1875, 18 Stat. 470 (1875) (current version at 28 U.S.C. $§ 1331$ $(2000))$. 
right $^{49}$ - a jurisdictional bar that lasted into the twentieth century. ${ }^{50}$ Though section 25 protected federal rights, it is inconsistent with textual interpretations that would mandate federal court review of all cases of a particular type under Article III. Further, to this day the Court still may not hear appeals of state court cases between parties of diverse citizenship, ${ }^{51}$ and amount-in-controversy requirements have barred federal court jurisdiction over cases not meeting the requirements since the first Judiciary Act. ${ }^{52}$ These types of cases fall within the Article III judicial power yet have historically been excluded by Congress from federal court jurisdiction.

Supreme Court precedent has also supported Congress's power to curtail federal lower-court jurisdiction, at least in certain cases. ${ }^{53}$ While there are certainly intriguing arguments that favor those who defend mandatory federal court jurisdiction over all cases within the Article III judicial power, the proponents of these theories are significantly disadvantaged by history.

Professor Amar has looked even further into the text of Article III, arguing that the use of the term "all" before the subject-based categories of cases in Article III, Section 2, Clause 1 requires Congress to vest jurisdiction for all of those cases in some federal court. He concludes that Congress can only limit the jurisdiction of the types of cases that

${ }^{49}$ The Judiciary Act of 1789 granted the Supreme Court appellate jurisdiction over state court cases involving:

[T] he validity of a treaty or statute of, or an authority exercised under the United States, and the decision is against their validity; or where is drawn in question the validity of a statute of, or an authority exercised under any State, on the ground of their being repugnant to the constitution, treaties or laws of the United States, and the decision is in favour of such their validity. Judiciary Act of 1789, ch. 20, § 25, 1 Stat. 73, 85 (1789); see also Fallon, supra note 17, at 1220 n.360 (noting that under the 1789 Judiciary Act, the Supreme Court's appellate jurisdiction over state cases "was limited to cases in which a state court rejected a claim of federal right").

${ }^{50}$ See Act of Dec. 23, 1914, ch. 2, 38 Stat. 790 (1914) (granting the Supreme Court the power to hear appeals, "by certiorari or otherwise," over state court decisions in favor of a federal right).

${ }^{51}$ See Sager, supra note 4, at 32 ("[T] he Court has never been empowered to review state court litigation between private parties of diverse citizenship.”).

${ }^{52}$ See CHEMERINSKY, supra note 4, § 3.3., at 192 (stating that amount-in-controversy "requirements have existed since the Judiciary Act of 1789").

53 See Sager, supra note 4, at 32 ("[I]n the pertinent opinions, the Court displays an almost unseemly enthusiasm in discussing Congress' power to lop off diverse heads of the Court's article III jurisdiction."); sources cited supra note 37 (suggesting that Congress has plenary power to limit federal jurisdiction). 
do not have this modifier. ${ }^{54}$ Amar's argument avoids several of the pitfalls of prior views of mandatory federal court jurisdiction. While it is perhaps the best comprehensive mandatory theory to date, his argument has been challenged on several fronts, most notably its incongruity with the 1789 Judiciary Act, ${ }^{55}$ a charge that Amar strongly disputes. ${ }^{56}$

Another set of arguments concedes that the text of the Constitution gives Congress power to remove federal court jurisdiction but contends that other factors external to the text of Article III limit this power. Preeminent among these structural arguments is the assertion that the Supreme Court serves "essential functions" in the constitutional plan by maintaining the supremacy of federal law and uniformity in its application, and that Congress cannot curtail federal court jurisdiction in a way that would limit these functions. ${ }^{57}$ The fundamental problem with the "essential functions" theory is that it has not been strongly rooted in constitutional text and fails to explain why the Judiciary Act of 1789 limited federal court jurisdiction in a way that did not promote uniformity of law. ${ }^{58}$

A more holistic approach looks to other constitutional rights and provisions, noting that any jurisdiction-stripping bill must be constitutionally valid not only under Article III, but under other constitutional provisions as well. ${ }^{59}$ For example, it is obvious that a bill taking federal jurisdiction away from a case filed by any member of a particular race

${ }^{54}$ See Amar, supra note 44, at 240 ("[A]lthough the judicial power must extend to all cases in the first three categories, [modified by the word "all"] it may, but need not, extend to all cases in the last six. The choice ... in the latter set of cases seems to be given to Congress ....").

${ }^{55}$ See Meltzer, supra note 34, at 1575-76 (responding to Amar's theory of mandatory jurisdiction); Redish, supra note 40, at 1647 (same).

${ }^{56}$ See Amar, supra note 10, at 1515-41 (responding to challenges which allege that the author's theory is inconsistent with the Judiciary Act of 1789).

${ }^{57}$ See Hart, supra note 17, at 1365 ("[T] he exceptions must not be such as will destroy the essential role of the Supreme Court in the constitutional plan.”); Ratner, supra note 8, at 160-67 (discussing the essential functions theory of jurisdiction).

${ }^{58}$ For example, the Judiciary Act of 1789 strictly limited Supreme Court appellate review of the federal circuit courts, thus limiting uniformity of interpretation of federal law. See infra note 154 (finding that Supreme Court review of civil cases was limited and review of criminal cases foreclosed by the Judiciary Act of 1789).

${ }^{59}$ See Williams v. Rhodes, 393 U.S. 23, 29 (1968) (finding that congressional powers "are always subject to the limitation that they may not be exercised in a way that violates other specific provisions of the Constitution"); Sager, supra note 4 , at 37 ("[W]hen Congress undertakes to limit jurisdiction, it is fully bound by the constitutional limitations that ordinarily constrain its behavior.”). 
would be unconstitutional under the Fifth Amendment. ${ }^{60}$ Similarly, even in less extreme cases, Congress's ability to limit the jurisdiction of federal courts must comply with due process concerns, among other constitutional protections. Supreme Court precedent supports this argument: in United States v. Klein, ${ }^{61}$ the Court struck down a jurisdiction-stripping law because the law abridged the President's pardon power under Article II, Section 2 of the Constitution. ${ }^{62}$

Some scholars therefore contend that congressional curtailment of federal court jurisdiction solely for substantive political issues would run afoul of one or more constitutional provisions, arguing, for example, that the jurisdictional law would be enacted with a motive to cause an unconstitutional result. ${ }^{63}$ These arguments are grounded in the correct foundation that the jurisdictional law itself cannot violate any other constitutional provisions. However, the applicability of this argument to most jurisdiction-stripping proposals is questionable, in that most proposals would be facially neutral regarding a constitutional right. ${ }^{64}$ Although the proposals may be intended to allow state courts to rule differently than a federal court, it would be difficult to establish improper legislative motive. ${ }^{65}$ For example, the laws could be attributed legitimate justifications, such as delegating review to state courts as part of their legitimate role in the federal system. Since state courts are presumed competent to hear issues of federal or constitu-

${ }^{60}$ See Tribe, supra note 4, at 140 (arguing that " $[\mathrm{t}]$ he framers cannot lightly be charged with having left open a clear path to such total obliteration of the constitutional enterprise" as would exist were jurisdictional laws not subject to other constitutional requirements); $c f$. Bolling v. Sharpe, 347 U.S. 497, 499 (1954) (holding that the due process clause of the Fifth Amendment protects the same values as the equal protection clause of the Fourteenth Amendment, making it effectively applicable against the federal government).

${ }^{61} 80$ U.S. (13 Wall.) 128 (1871).

${ }^{62} \mathrm{Id}$. at 147 ("The rule prescribed is also liable to just exception as impairing the effect of a pardon, and thus infringing the constitutional power of the Executive.").

${ }^{63}$ See, e.g., Sager, supra note 4 at 68-80 (looking at the role of congressional motive when determining the constitutionality of jurisdiction-stripping laws).

${ }^{64}$ See Tribe, supra note 4, at $153 \mathrm{n} .94$ (" $[\mathrm{S}]$ ome courts might be reluctant to rely on judicial findings of forbidden congressional motive to invalidate jurisdictional restrictions that are neutral on their face and that are too ambiguous in their effects to be struck down on an impact basis alone.").

${ }^{65}$ See Gunther, supra note 8, at 919 ("[F] atal flaws exist in the frequently made argument that the Court should strike down jurisdiction-stripping laws because of such allegedly improper 'motivation.' All recognize the difficulty of proving legislative motive, and the Court has expressed a reluctance (in the McCardle case, for example) to venture into that terrain." (footnote omitted)). 
tional law, it is not clear that relegating particular issues to exclusive state court resolution can be presumed to direct a particular outcome.

\section{Views of the Constitution's Framers and Ratifiers}

Despite some historical and textual problems, those arguing for limits on Congress's power to curtail federal court jurisdiction have presented strong evidence that the Constitution's framers and ratifiers generally intended and anticipated a strong role for the federal judiciary in hearing issues of national importance and viewed such a role as fundamental to the constitutional plan and federal supremacy. During the Constitutional Convention, some framers expressed great distrust for the state courts and pushed for a strong federal judiciary to protect constitutional rights. James Madison, for example, remarked that "[c]onfidence [cannot] be put in the State Tribunals as guardians of the National authority and interests." ${ }^{66}$ Similarly, Edmund Randolph argued that "the Courts of the States can not be trusted with the administration of the National laws." ${ }^{\prime 7}$ While others had greater respect for state courts and did not favor the establishment of inferior federal courts, this position was advanced with the explicit understanding that, as John Rutledge argued, "the right of appeal to the supreme national tribunal [was] sufficient to secure the national rights [and] uniformity of Judgm[en]ts." ${ }^{, 8}$ The Madisonian Compromise, which resulted from these competing beliefs, gave Congress discretion to create inferior federal courts and was grounded in the understanding that state judges were competent to hear federal issues with "ultimate review by the Supreme Court . . . assur[ing] sufficient supremacy and uniformity." ${ }^{69}$ As Professor Amar has concluded, "the clear understanding of the Convention was that state court decisions must be reviewable by the national judiciary."

${ }^{66} 2$ The ReCORDS OF THE CONSTITUTIONAL CONVENTION OF 1787, at 27 (Max Farrand ed., 1911) (July 17) [hereinafter 2 Farrand's RECORDS].

${ }^{67} 2 \mathrm{id}$. at 46 (July 18).

${ }^{68} 1 \mathrm{id}$. at 134 (June 5).

${ }^{69}$ Gunther, supra note 8, at 906; see Clinton, supra note 8, at 753-54 (discussing how the Madisonian Compromise sought to achieve uniformity by allowing review of federal issues by federal judges who "were constitutionally guaranteed judicial independence"); Ratner, supra note 8, at 161-62 (recognizing among the constitutional framers an "explicit assumption that the Supreme Court would exercise appellate jurisdiction over state court judgments" where there were no inferior courts).

${ }^{70}$ Amar, supra note 44, at 249. 
The debates during the ratification of the Constitution also demonstrated a general assumption among the supporters of the Constitution that Congress did not have unlimited power to limit federal court jurisdiction. As Professor Clinton has shown, the federalist defenders of the Constitution, in response to antifederalist attacks on the expansiveness of Article III judicial power, consistently stressed the importance of federal court jurisdiction as essential to guarantee federal supremacy. ${ }^{71}$ In The Federalist No. 82, Alexander Hamilton, discussing whether the Supreme Court could hear appeals from state supreme courts, wrote that

\begin{abstract}
an appeal would certainly lie from [State courts hearing federal question cases based on concurrent jurisdiction], to the Supreme Court of the United States. . . Either this must be the case or the local courts must be excluded from a concurrent jurisdiction in matters of national concern, else the judiciary authority of the Union may be eluded at the pleasure of every plaintiff or prosecutor. Neither of these consequences ought, without evident necessity, to be involved; the latter would be entirely inadmissible, as it would defeat some of the most important and avowed purposes of the proposed government, and would essentially embarrass its measures. ... The courts of the [states] will of course be natural auxiliaries to the execution of the laws of the Union, and an appeal from them will as naturally lie to that tribunal which is destined to unite and assimilate the principles of national justice and the rules of national decisions. $^{72}$
\end{abstract}

Hamilton continued by remarking that " $[\mathrm{t}]$ he evident aim of the plan of the convention is, that all the causes of the specified classes shall, for weighty public reasons, receive their original or final determination in the courts of the Union." ${ }^{, 3}$ Hamilton's writings evince a firm belief that "matters of national concern" must, under the constitutional plan, be heard ultimately in a federal court—a belief evidently rooted in concerns of federal supremacy. ${ }^{74}$

How, then, can this evidence be squared with the traditional argument that Congress is free to suspend this important element of constitutional structure as the political tides change? Professor Melt-

${ }^{71}$ See Clinton, supra note 8, at 810-28 (analyzing the statements of constitutional ratifiers regarding the scope of the federal judicial power).

${ }^{72}$ The Federalist No. 82, at 253-54 (Alexander Hamilton) (Roy P. Fairfield ed., 2d ed. 1966).

${ }^{73} I d$. at 254.

${ }^{74} I d$. By "specified classes," Hamilton could be interpreted to be referring to all categories of Article III power. However, given his other arguments, he appears to be referring to the classes he has specified in his writings-that is, "matters of national concern" or "national decisions." 
zer notes the discontinuity between history and the positions on both sides of the debate. Those who argue that Congress cannot impede the Supreme Court's "essential role" in upholding the supremacy of federal law, or who find mandatory jurisdiction rooted in Article III, have failed to identify a textual basis in the Constitution that meshes with the historical evidence. Yet supporters of jurisdiction-stripping proposals "must assign great weight to the exceptions clause, which was rather inconspicuous in the constitutional debate," and also have difficulty addressing the evidence that the framers intended a strong role for the federal judiciary as essential to the constitutional plan. ${ }^{75}$

The preceding discussion sets up two basic propositions that must be harmonized. First, based on the long history of jurisdictional restrictions, Congress has some power, stemming from Article III, to limit federal court jurisdiction and leave areas of law to resolution in state courts. Yet this power is only the power to make "exceptions," which necessarily implies a counteracting and supreme principle that must remain. ${ }^{76}$ This leads to the second proposition that the framers intended the federal judiciary, particularly the Supreme Court, to have an essential role under the constitutional plan in reviewing important national issues. ${ }^{77}$ These two propositions roughly equate to the ideologies of modern federalism and nationalism, respectively, and an inquiry into judicial federalism, as it applies to the jurisdictionstripping debate, is instructive.

\section{JUDICIAL FEDERALISM}

\section{A. The Federalist and Nationalist Viewpoints}

Professor Fallon has identified two models of judicial federalism that generally explain two common categories of competing constitutional theories: a federalist model and a nationalist model. ${ }^{78}$ The federalist model, which is most dominant in current Supreme Court cases, views the states as important entities of government and emphasizes that state courts are "constitutionally as competent as federal courts to adjudicate federal issues and to award remedies necessary to

\footnotetext{
${ }^{75}$ Meltzer, supra note 34 , at 1609-10.

${ }^{76}$ See Tribe, supra note 4 , at 135 (" $[\mathrm{T}]$ he reference to exceptions and regulations indicates that something substantial is to remain after Congress' subtractions have been performed.").

${ }_{77}$ See supra notes 72-74 and accompanying text.

78 See Fallon, supra note 17, at 1151-64 (describing the features of both models).
} 
vindicate federal constitutional norms." ${ }^{, 79}$ This model presumes that when Congress enacts jurisdictional legislation, it "regards the state courts as being as competent as federal courts to adjudicate federal issues fairly and expeditiously."

One recent example of the federalist model is Idaho $v$. Coeur d'Alene Tribe of Idaho, ${ }^{81}$ in which Justice Kennedy, joined only by Chief Justice Rehnquist, argued that the Supremacy Clause did not require federal courts to be available to hear federal law cases against state officials except in limited circumstances. Justice Kennedy argued that "[a] doctrine based on the inherent inadequacy of state forums would run counter to basic principles of federalism," and that "[i]nterpretation of federal law is the proprietary concern of state, as well as federal, courts." ${ }^{, 2}$

The nationalist model, as identified by Professor Fallon, finds a "strong conception of national supremacy" embodied in the Constitution and views the Constitution as "contemplat[ing] a special role for the federal judiciary, different in kind from that assigned to state courts, in ensuring the supremacy of national authority. ${ }^{, 83}$ Nationalists therefore view federal courts as more competent and effective than state courts in enforcing constitutional rights. ${ }^{84}$ It is this view that won the day in Coeur d'Alene Tribe, as a majority of the Court reaffirmed continued adherence to traditional Young doctrine, "acknowl-

${ }^{79}$ Id. at 1153 (emphasis omitted).

${ }^{80} I d$. at 1154 (emphasis omitted).

51 521 U.S. 261, 275 (1997)

${ }^{82}$ Id. at 275 (opinion of Kennedy, J., joined by Rehnquist, C.J.). Justice Kennedy went on to write:

It is the right and duty of the States, within their own judiciaries, to interpret and to follow the Constitution and all laws enacted pursuant to it, subject to a litigant's right of review in this Court in a proper case. The Constitution and laws of the United States are not a body of law external to the States, acknowledged and enforced simply as a matter of comity. The Constitution is the basic law of the Nation, a law to which a State's ties are no less intimate than those of the National Government itself. ... It would be error coupled with irony were we to bypass the Eleventh Amendment, which enacts a scheme solicitous of the States, on the sole rationale that state courts are inadequate to enforce and interpret federal rights in every case.

Id. at 275-76. Justice Kennedy sought to narrow the Young exception by requiring a case-by-case analysis of factors including whether applying the exception would "upset the balance of federal and state interests that it embodies." Id. at 277 (quoting Papasan v. Allain, 478 U.S. 265, 277 (1986)).

${ }^{83}$ Fallon, supra note 17, at 1158-59 (emphasis omitted).

${ }^{84}$ See id. at 1161 (describing factors which contribute to federal courts' arguably more effective protection of federal rights). 
edg[ing] the importance of having federal courts open to enforce and interpret federal rights." ${ }^{, 55}$

These countervailing views of judicial federalism are strongly at play in two areas of constitutional debate relevant here: Congress's power to curtail federal court jurisdiction ${ }^{86}$ and state sovereign immunity. ${ }^{87}$ An inquiry into the latter provides a great deal of insight into the former.

\section{B. Sovereign Immunity and Ex parte Young}

A majority of the current Supreme Court firmly upholds a broad view of state sovereign immunity from private lawsuits. While the validity of the Court's sovereign immunity jurisprudence is outside the scope of this Comment and is already the subject of much scholarly analysis, ${ }^{88}$ a brief overview of sovereign immunity law as it stands today is appropriate. Historically, the Court has found state sovereign immunity to be rooted in the Eleventh Amendment, which dictates: "The Judicial power of the United States shall not be construed to extend to any suit in law or equity, commenced or prosecuted against one of the United States by Citizens of another State, or by Citizens or Subjects of any Foreign State." ${ }^{\not 9}$ The Eleventh Amendment was ratified in response to the 1793 case of Chisholm $v$. Georgia, ${ }^{90}$ which held that Article III of the Constitution, by extending to the judiciary the power to hear controversies "between a State and Citizens of another State," allowed not only suits by the states against those citizens, but also suits against the states by those citizens. ${ }^{91}$ The Eleventh Amendment, by its text, explicitly bars the latter.

Almost a century later, the Court in Hans $v$. Louisiana ${ }^{92}$ established that the Eleventh Amendment bars not only a suit against a state brought by citizens of another state, as the text dictates, but also a suit

${ }^{85}$ Coeur d'Alene Tribe, 521 U.S. at 293 (O'Connor, J., concurring in part and concurring in the judgment).

${ }^{86}$ Fallon, supra note 17 at 1215-16 (discussing the roles of the nationalist and federalist models in the jurisdiction-stripping debate).

${ }^{87}$ See id. at 1198 (noting that the intersection of sovereign immunity and the Ex parte Young doctrine represents the boundary between nationalist and federalist values).

${ }^{88}$ For a good overview of the Court's sovereign immunity jurisprudence and scholarly commentary thereon, see CHEMERINSKY, supra note 4 , at $\$ 7$.

${ }^{89}$ U.S. CONST. amend XI.

${ }^{90} 2$ U.S. (2 Dall.) 419 (1793).

${ }^{91} I d$. at 479 .

92134 U.S. 1 (1890). 
against a state brought by its own citizens. ${ }^{93}$ The decision in Hans provided the starting point for the Court's current sovereign immunity jurisprudence. The Court in recent years has significantly broadened the scope of its sovereign immunity interpretation, holding that state sovereign immunity was not derived from the Eleventh Amendment, but rather was a fundamental aspect of the sovereignty possessed by the states before the Constitution was ratified and preserved by the Constitution through its federal structure. ${ }^{94}$ Rather than establishing state sovereign immunity, the Eleventh Amendment merely clarified the Constitution and rectified Chisholm's error by restoring the Constitution's true meaning - that the states retain "'a residuary and inviolable sovereignty" essential to their dignity within the federalist system. $^{95}$ Thus, the Court's sovereign immunity law, as it stands today, is strongly rooted in concerns of federalism and the dignity of the states.

A serious consequence arises if sovereign immunity were to protect states from all private lawsuits, in that individuals would be rendered unable to sue states to prevent violations of the Constitution and federal law. However, several methods exist to avoid this harsh result. The first is state consent to suit-that is, a state can waive its sovereign immunity and allow individuals to sue in state or federal court. $^{96}$ Also, the Court has held that Congress can abrogate the sovereign immunity of states when acting appropriately under power granted by Section 5 of the Fourteenth Amendment. ${ }^{97}$ Finally, the Court has established an exception to the sovereign immunity doctrine based on the case of Ex parte Young. ${ }^{98}$ It is this last method that is of particular relevance to the issue of jurisdiction stripping.

The Court in Young established the principle that, although a suit against a state might be barred by sovereign immunity, an individual may sue state officials in their official capacity to prevent a violation of

${ }^{93} I d$. at 15

${ }^{94}$ See Alden v. Maine, 527 U.S. 706, 713-30 (1999) (outlining the history and theory behind state sovereign immunity).

${ }^{95}$ See id. at 715 (quoting The Federalist No. 39, at 117 (James Madison) (Roy P. Fairfield ed., 2d ed. 1966))

${ }^{96}$ See id. at 755 (" $[\mathrm{S}]$ overeign immunity bars suits only in the absence of [state] consent.").

${ }^{97}$ See id. at 756 ("Congress may authorize private suits against nonconsenting States pursuant to its $\$ 5$ enforcement power.”) (citing Fitzpatrick v. Bitzer, 427 U.S. 445 (1976)).

${ }_{98} 209$ U.S. 123 (1908). The idea that the Eleventh Amendment's jurisdictional limitation applies to suits against states but not state officials was first proffered by Chief Justice Marshall in Osborn v. Bank of the United States, 22 U.S. (9 Wheat.) 738, 84243 (1824). 
constitutional rights. According to the Court in Young, state officials who act in violation of the Constitution are stripped of their official capacity and, thus, of the protection of state sovereign immunity. ${ }^{99}$ The Court later held that actions taken by state officials were still deemed state action under the Fourteenth Amendment. ${ }^{100}$ This "obvious fiction," as Justice Kennedy has called it, ${ }^{101}$ created a situation where "an official's unconstitutional conduct constitutes state action under the Fourteenth Amendment but not the Eleventh Amendment."102

The Court in Edelman $v$. Jordan ${ }^{103}$ recognized the importance of Young as "permitt[ing] the Civil War Amendments to the Constitution to serve as a sword, rather than merely as a shield, for those whom they were designed to protect." ${ }^{104}$ The Young doctrine has been refined over the past century, and as it stands today, only allows suit for prospective injunctive or declaratory relief against state officials for violations of federal law. ${ }^{105}$

The survival of the Young doctrine is essentially a recognition of the importance of providing a federal forum to hear issues of federal law, ${ }^{106}$ and the Supreme Court has consistently couched the constitu-

99209 U.S. at 159-60.

${ }^{100}$ Home Tel. \& Tel. Co. v. City of L.A., 227 U.S. 278, 286-87 (1913); see also CHEMERINSKY, supra note $4, \S 7.5$, at 422 ("There the Court held that individual conduct not entitled to Eleventh Amendment immunity is nonetheless state action for purposes of the Fourteenth Amendment.").

${ }^{101}$ Idaho v. Coeur d'Alene Tribe of Idaho, 521 U.S. 261, 270 (1997); see also Verizon Md., Inc. v. Pub. Serv. Comm'n of Md., 535 U.S. 635, 649 (2002) (Kennedy, J., concurring) (calling Ex parte Young a "legal fiction").

${ }^{102}$ Pennhurst State Sch. \& Hosp. v. Halderman, 465 U.S. 89, 105 (1984). Fallon elaborates on this irony, noting that:

$[\mathrm{S}]$ tate officials ... can be sued for injunctions on the theory that they are not

"the state" and thus not entitled to eleventh amendment protection. Somewhat paradoxically, the Young fiction applies even in suits ... under the fourteenth amendment, which forbids only those deprivations of rights that are caused by a "state."

Fallon, supra note 17, at 1197 (footnote omitted).

103415 U.S. 651,664 (1974)

104 Id. at 664.

105 See Verizon Md., Inc., 535 U.S. at 645 ("In determining whether the doctrine of Ex parte Young avoids an Eleventh Amendment bar to suit, a court need only conduct a 'straightforward inquiry into whether [the] complaint alleges an ongoing violation of federal law and seeks relief properly characterized as prospective." (quoting Coeur d'Alene Tribe, 521 U.S. at 296 (O'Connor, J., concurring in part and concurring in the judgment))).

106 See Fallon, supra note 17, at 1197 (“[Young's] plain policy was to permit the vindication of federal rights in federal court, implicitly on the assumption that a federal forum would ensure more effective vindication of federal constitutional claims."). 
tional basis for this requirement in terms of federal supremacy. In 1983, the Court recognized the Young doctrine as "necessary to permit the federal courts to vindicate federal rights and hold state officials responsible to 'the supreme authority of the United States." "107 Two years later, the Court highlighted the prospective relief of Young as "giv[ing] life to the Supremacy Clause" because "[r]emedies designed to end a continuing violation of federal law are necessary to vindicate the federal interest in assuring the supremacy of that law." ${ }^{108}$ More recently, seven Justices reaffirmed the Court's adherence to the Young doctrine in Idaho v. Coeur d'Alene Tribe of Idaho, acknowledging "the importance of having federal courts open to enforce and interpret federal rights." 109

The Court in Pennhurst described Young's intersection with its sovereign immunity jurisprudence as a balancing of interests-“" "the culmination of efforts by this Court to harmonize the principles of the Eleventh Amendment with the effective supremacy of rights and powers secured elsewhere in the Constitution." "'10 In determining that the Young exception did not apply in a state-law suit, the Pennhurst Court illustrated this balancing structure by weighing state sovereignty interests against the federal supremacy interest. The Court pointed out that when a state official is alleged to violate state law, "the entire basis for the doctrine of Young... disappears" because a grant of relief from a violation of state law "does not vindicate the supreme authority of federal law." the federal supremacy interest implicated in determining whether concerns of federalism are outweighed when applying the Young exception to sovereign immunity. ${ }^{112}$

Although there is some ambiguity as to the Supreme Court's true basis for upholding the Young exception, leading many to chal-

${ }^{107}$ Pennhurst, 465 U.S. at 105 (quoting Ex parte Young, 209 U.S. 123, 160 (1908)).

${ }^{108}$ Green v. Mansour, 474 U.S. 64, 68 (1985).

${ }^{109}$ Coeur d'Alene Tribe, 521 U.S. at 293 (O'Connor, J., concurring in part and concurring in the judgment); see id. (Souter, J., dissenting) (agreeing with O'Connor's continued adherence to the Young doctrine).

${ }^{110}$ Pennhurst, 465 U.S. at 105 (quoting Perez v. Ledesma, 401 U.S. 82, 106 (1971) (Brennan, J., concurring in part and dissenting in part).

111 Id. at 106.

${ }^{112}$ Note that this balancing of interests takes place at the categorical level, and is not the same as Justice Kennedy's individualized, case-by-case approach to the Young doctrine that was rejected by a majority of the court in Coeur d'Alene Tribe, 521 U.S. at 280. 
lenge the validity of this "obvious fiction," sible explanations. The first is that the Young doctrine is rooted in and required by the Supremacy Clause of the Constitution; the Court essentially said as much in Green and Pennhurst. ${ }^{114}$ Alternatively, the Young exception might be part of a broader mode of constitutional interpretation of jurisdiction that looks to the importance of the merits of the claim rather than solely the statutory basis for jurisdiction-an extraconstitutional tradition rooted in courts' historical equity powers. ${ }^{115}$ Professor Laura Fitzgerald has argued that, although the Supreme Court has conventionally required that subject matter jurisdiction be a prerequisite for the exercise of Article III judicial power, ${ }^{116}$ in several significant cases the Court has exchanged this "jurisdiction-first view for a more malleable approach that dispenses federal judicial power based on how important the Court considers the federal interests at stake, on the merits, and how necessary the Court considers it to provide a federal remedy where those interests are impaired." 17 According to Fitzgerald, "[t]his merits-first tendency has led the Court to claim the judicial power to act even where constitutional or statutory obstacles seriously compromise subject matter jurisdiction." ${ }^{118}$ As a central example of this merits-first trend, Fitzgerald points to sovereign immunity cases and argues that, although most are driven by a jurisdiction-first analysis, the Court's preservation of the Young exception is a merits-based effort to vindicate federal rights. ${ }^{119}$

Whether Professor Fitzgerald is correct that Young falls within a distinct merits-first analysis or whether Young is rooted in the constitutional Supremacy Clause, the Court has consistently held that the

113 Id. at 270; supra note 101.

114 See supra notes 108, 110-11 and accompanying text.

115 See Laura S. Fitzgerald, Is Jurisdiction Jurisdictional?, 95 Nw. U. L. REV. 1207, 1209 (2001) ("When the Supreme Court disregards its jurisdiction-first rhetoric and instead dispenses federal judicial power based on how important it considers the federal interests at stake, on the merits, the Court acts like a pre-constitutional court of equity-not the creature of a limited and limiting Article III.").

${ }^{116}$ See id. at 1207, 1214-16 ("Without jurisdiction the court cannot proceed at all in any cause. Jurisdiction is power to declare the law, and when it ceases to exist, the only function remaining to the court is that of announcing the fact and dismissing the cause." (quoting Ex parte McCardle, 74 U.S. (7 Wall.) 514 (1869))).

117 Id. at 1207.

118 Id.

119 See id. at 1220 ("[T]he Court continues to defend and preserve Young based simply on the compelling need to have federal courts open to enforce federal law against recalcitrant states, despite the limit on the federal judicial power that state sovereign immunity has been held to impose."). 
Young exception is primarily based on maintaining important federal government interests despite an apparent jurisdictional bar to suit. Similar interests apply when the jurisdictional bar is based not on sovereign immunity but rather congressional jurisdictional restrictions under Article III.

\section{Federal COURTS, CONSTITUTIONAL SUPREMACY, AND FEDERALISM: A COMPREHENSIVE VIEW}

The "essential functions" view of federal court jurisdiction, as previously posited, ${ }^{120}$ was flawed because it tried to do too much while failing to adequately ground itself in a strongly supportive textual theory of the Constitution. But a narrowed version of the "essential functions" theory, focusing on the Supremacy Clause yet integrating concerns of federalism, might more appropriately represent the text of the Constitution, the views of the framers, and the historical applications thereafter in laws such as the 1789 Judiciary Act. It would also avoid Professor Amar's criticism of the "essential functions" theory as failing to provide "a determinate boundary between what Congress may do consistently with article III, and what it may not." ${ }^{, 21}$ Under this theory, the clear minimum requirement upon Congress would be to maintain ultimate federal court review of state court rulings against constitutional claims.

\section{A. Constitutional Supremacy}

In considering a constitutional supremacy theory of jurisdiction, it is important to first recognize that the Supremacy Clause does not establish a monolithic "federal supremacy" interest; rather, the Constitution sets up a textual hierarchy that entrenches itself at the top: "This Constitution, and the Laws of the United States which shall be made in Pursuance thereof; and all Treaties made ... shall be the supreme Law of the Land...."122 The Constitution is absolutely supreme; congressional laws only share in that supremacy when they comport with the Constitution. ${ }^{123}$ While this is seemingly self-evident,

${ }^{120}$ See supra text accompanying notes 57-58.

${ }^{121}$ Amar, supra note 10, at 1514.

${ }^{122}$ U.S. CONST. art. VI, cl. 2.

123 See Marbury v. Madison, 5 U.S. (1 Cranch) 137, 180 (1803) (pointing out that the Supremacy Clause sets up a hierarchy with the Constitution above federal laws and holding that this confirms and strengthens the principle that "a law repugnant to the constitution is void; and that courts, as well as other departments, are bound by that 
it clarifies that the general "federal supremacy" interest can only be challenged in two ways relevant to this discussion: when a federal law is alleged to violate the Constitution (thereby threatening the supremacy of the Constitution) and when a state law is alleged to violate the Constitution or conflict with a federal statute (thereby threatening the supremacy of either the Constitution or the federal law, respectively). As the Supreme Court is "the constitutional instrument for implementing the supremacy clause" recognized in the Young line of cases that some federal forum is necessary to vindicate the Supremacy Clause ${ }^{125}$ - a jurisdictional theory integrating the concerns of the Supremacy Clause provides a textual basis for an argument that constitutional supremacy places a necessary limit on Congress's power to curtail federal court jurisdiction. ${ }^{126}$

Proponents of the "essential functions" theory err when interpreting the federal supremacy interest by failing to limit themselves to the preceding self-evident proposition, often basing their arguments in the general structure of government ${ }^{127}$ or a broad view of "federal su-

instrument.”); The Federalist No. 78, at 228-29 (Alexander Hamilton) (Roy P. Fairfield ed., 2d ed. 1966) ("No legislative act . . contrary to the Constitution, can be valid. ... A constitution is, in fact, and must be regarded by the judges, as a fundamental law.").

${ }^{124}$ Ratner, supra note 8, at 160-61. Some may view the Supremacy Clause as supporting an argument in favor of jurisdiction stripping because it dictates that judges in the states are bound by federal law, implying that states are fully competent to decide issues of federal law. However, there is a difference between a state's competence to decide such issues and a state's final authority to be the sole arbiter of such a decision. "[A]cknowledging the interpretive function of federal courts [does not] suggest that state courts are inadequate to apply federal law"-it simply recognizes that there is an important supremacy interest in allowing federal courts to have authority to review certain state decisions. Idaho v. Coeur d'Alene Tribe of Idaho, 521 U.S. 261, 293 (1997) (O'Connor, J., concurring in part and concurring in the judgment).

${ }^{125}$ See supra text accompanying notes 72-75.

${ }^{126}$ At the very least, whatever justifies the current Young exception would be applicable here, even if it is not the Supremacy Clause. For example, the same important interests that drive Young under a merits-first approach to jurisdiction, such as vindication of constitutional rights in federal court, see supra notes 107-09 and accompanying text, are equally at issue when Congress strips federal courts of jurisdiction to hear particular constitutional claims.

${ }^{127}$ Professor Ratner relies in part on the Supreme Court's place within the structure of government-that "[a]s the sole tribunal established by the Constitution, it provided the only certain instrumentality for securing" supremacy and uniformity of federal law. Ratner, supra note 8, at 162 . Ratner's version of the "essential functions" theory would require "some avenue [to] remain open to permit ultimate resolution by the Supreme Court of persistent conflicts between state and federal law or in the interpretation of federal law by lower courts." Id. at 161. Professor Sager also relies on a general concept of "the balance of federal authority," Sager, supra note 4, at 55, and 
premacy." ${ }^{218}$ Because the Constitution is supreme over federal statutes, there is a fundamental difference between nonconstitutional federal claims, which merely seek a remedy under federal statutes, and constitutional claims, which seek to vindicate constitutional rights, in that the supremacy of the Constitution is only threatened in the latter instance.

Nonconstitutional federal claims seek a remedy under federal statutes and in the process clarify the meaning of those statutes. There is no real harm done to the federal supremacy of federal law when Congress expressly and exclusively delegates those interpretive determinations to state courts, even if there is no federal court review of their decisions. ${ }^{129}$ Congress need not make a particular law at all and need not even create inferior federal courts to hear a claim under a particular law, and the Supreme Court has firmly established that the framers of the Constitution trusted state courts to interpret federal law competently. Because Congress has the power to define inferior federal court jurisdiction, Congress can, in effect, delegate entire areas of federal law for exclusive state interpretation and application. ${ }^{130}$

the life tenure provision and salary diminution prohibition, $i d$. at $63-65$, to find an implied requirement of federal court jurisdiction.

${ }^{128}$ Professor Ratner views the Supremacy Clause as mandating "that there shall be one supreme federal law throughout the land," and did not distinguish between constitutional claims and nonconstitutional claims. Ratner, supra note 8 , at 160 . Professor Sager does recognize the distinct importance of Supreme Court review for constitutional claims but never explained why he was distinguishing between constitutional claims and nonconstitutional federal claims for purposes of federal supremacy. In fact, it is never clear that he truly distinguishes between the two, as he refers several times to mandatory federal review of state compliance with "federal law," not just constitutional law. See, e.g., Sager, supra note 4, at 57. Nevertheless, as Professor Redish points out, Sager's reliance on a general idea of federal supremacy, as he analyzes it, could not logically be limited to constitutional claims because the Supremacy Clause "is not limited in its dictates to matters of constitutional law." Redish, supra note 42, at 148.

${ }^{129}$ One might respond that Congress cannot authorize the state courts to raise state law above federal law, as this would directly violate the Supremacy Clause. However, there is a difference between allowing state law to trump federal law and allowing states courts to interpret federal law. By deferring to state courts the interpretation of federal laws, Congress would effectively be saying that state courts are competent to be the exclusive interpreters of its laws. In doing so, Congress is taking the risk that state courts would misconstrue its intent, but it is a risk that Congress is explicitly assuming.

${ }^{130}$ Amar argues that the mandatory nature of Article III jurisdiction means that the government cannot do this, but this assumes Article III is indeed fully mandatory per his textual argument, not that it conflicts with a theory of constitutional supremacy. See Amar, supra note 44, at 251 n.150. If Amar's mandatory argument were adopted, it would subsume the constitutional supremacy theory posed here; were it not adopted, the argument here survives independently. Amar also contends that a coextensiveness principle requires that national judges expound congressional laws, argu- 
And, given Congress's textual power to make exceptions to Supreme Court review, ${ }^{131}$ it logically follows that Congress may prohibit Supreme Court review of state court decisions in those areas.

However, constitutional claims are a different matter. Whereas Congress makes its own laws and may, without violating federal supremacy, enable state courts to interpret and apply its own laws, Congress does not have authority to change the Constitution; it is a body of law above Congress. The constitutional supremacy interest rooted in the Supremacy Clause is of a different nature than that of federal law, and while Congress may exercise its power to control federal jurisdiction in nonconstitutional cases without running afoul of the Supremacy Clause, the same cannot be said in constitutional cases. ${ }^{132}$ Viewed from this perspective, the Supremacy Clause acts as an external constraint on congressional power over jurisdiction, much like the Due Process Clause or any other constitutional provision. Although state courts are competent to hear constitutional issues, and Congress is perhaps free to confine original jurisdiction over particular constitutional cases to state courts (because it may eliminate inferior federal courts altogether), ${ }^{133}$ Congress cannot use its exception power to eliminate federal court review of these state decisions, because doing so would threaten the supremacy of the Constitution, which must ultimately be interpreted in a federal court.

ing that "[a] congressional effort to shift final interpretive authority from federal to state courts is no more structurally supportable than a parallel effort to shift the President's power to veto laws to state governors." Amar, supra note 10, at 1511. While Amar proffers a strong argument, the distinction made in this Comment between constitutional and nonconstitutional interpretation of federal law evades this analogy. A federal court's interpretive power would only resemble a presidential veto when it strikes down federal law as unconstitutional, and the theory posed in this Comment would require federal court review of constitutional cases, maintaining the federal judicial check on unconstitutional congressional action. In situations where a federal court's interpretive role is nonconstitutional, congressional curtailment of jurisdiction does not eliminate or modify a check on its own power; it merely takes some of its interpretive business to a different company. The strength of the analogy to the presidential veto is also vitiated by a lack of textual basis for a congressional power to shift a President's veto power, while there is a textual basis for believing that Congress can curtail federal court jurisdiction. See supra text accompanying notes 29-38.

${ }^{131}$ See supra notes 38-40 and accompanying text (discussing Congress's power to create exceptions to the Supreme Court's appellate jurisdiction).

${ }^{132}$ See Amar, supra note 44, at 224 ("[S]ince Congress did not create the Constitution, it cannot oust the constitutionally-prescribed role of the national judiciary to decide all cases arising under that document.").

${ }^{133}$ See supra note 37 and accompanying text (discussing Congress's power to limit federal jurisdiction). 
This analysis follows the balancing structure set up in the Young line of cases. ${ }^{134}$ In the same way that the Pennhurst Court weighed the state sovereignty interests of the Eleventh Amendment against the interest in federal supremacy rooted in the Supremacy Clause, ${ }^{135}$ it is logical that the Court, if reviewing a jurisdiction-stripping proposal, could weigh Congress's Article III power to make exceptions to the Supreme Court's appellate jurisdiction against the interest in federal supremacy rooted in the Supremacy Clause. Just as the Pennhurst Court found that violation of state law by state officials presented no threat to federal supremacy, ${ }^{136}$ a weighing of a congressional jurisdiction-stripping proposal would yield an analogous result. Insofar as the proposal applies to nonconstitutional issues of federal law, it would present no threat to federal supremacy because Congress would be voluntarily foregoing federal court interpretation of its own laws; however, insofar as the proposal applies to constitutional issues, the proposal would present a strong threat to constitutional supremacy because congressional desire to confine resolution of constitutional issues to state courts does nothing to vitiate the important supremacy interest, upheld in the Young line of cases, in having federal courts available as the ultimate interpreters of those issues.

${ }^{134}$ Because the Young doctrine, when applicable, requires the availability of federal courts for trial-level litigation, one could respond that if the analogy to Young were valid, such a theory would necessarily require lower federal courts for the trial-level litigation of all constitutional cases in jurisdiction-stripping situations; after all, the Young doctrine is not satisfied merely with federal appellate review of state trials. This, then, would be antithetical to the Madisonian Compromise. However, such a consequence is unnecessary, as the Young doctrine developed under different circumstances where a background of congressionally-provided federal question jurisdiction was already in place. Thus, Congress was attempting to provide a federal trial forum for federal claims, an attempt that was stifled in certain cases by state sovereign immunity. The federal supremacy interest at stake could be viewed not only as an interest in vindicating substantive federal rights but also as an interest in upholding Congress's provision of federal trial courts for such claims. The result need not be the same in a situation in which Congress takes the opposite tack, seeking to strip federal courts of jurisdiction. In this situation, the federal interest in providing a federal trial-level court is vitiated. Further, the Supreme Court has stated that the Young exception is "so essential a part of our sovereign immunity doctrine" because the states retained sovereign immunity from suits in their own courts. Alden v. Maine, 527 U.S. 706, 748 (1999). Without Young's guarantee of a federal trial forum, there might be no trial court available to hear claims against a state. With jurisdiction stripping, state courts would remain available, so that concern is not applicable here.

${ }^{135}$ See supra notes $110-11$ and accompanying text.

${ }^{136} 465$ U.S. 89, 106 (1984). 


\section{B. Historical Support}

Not only does this theory comport with the underpinnings of the Young line of cases, it upholds the ideas and assumptions of the framers, who seemingly believed that important national issues would be reviewed by the Supreme Court. ${ }^{137}$ A constitutional supremacy theory of federal jurisdiction also avoids the historical pitfalls of other approaches that are "done in" by section 25 of the Judiciary Act of $1789 .{ }^{138}$ The Act did not allow appeals of state court decisions in favor of federal rights-yet these are precisely the types of cases that present no challenge to federal supremacy. ${ }^{139}$ If the state court is favoring a federal or constitutional right, it is actually overprotecting federal law. While there may be minor gaps between the Act of 1789 and a theory that would prevent Congress from restricting Supreme Court appellate review of constitutional cases, ${ }^{140}$ "section 25 of the Act . . was essentially a supremacy-assuring device." ${ }^{141}$

${ }^{137}$ See supra text accompanying notes 70-74.

138 Professor Redish's critique of similar arguments made by Professor Sager does not apply here, due to the differences between this theory and Sager's. As Redish notes, Sager's theory, though concerned with federal supremacy, was fundamentally based on the text of Article III alone, in particular the salary and tenure provisions. See Redish, supra note 42, at 144-45. In response to Sager's argument that Congress must use the federal courts to ensure that state courts were complying with federal law, Redish points out that "there is, by definition, no possibility of interference with federal supremacy [because] the federal government has chosen to deem acceptable whatever constructions of federal law the state courts develop." Id. at 147. While this is correct as applied to nonconstitutional interpretations of federal law by state courts, as reflected in Sager's theory, it is incorrect as applied to constitutional interpretations by state courts, to which the constitutional supremacy theory posited here is limited. In that Congress is subordinate to the supreme Constitution in the legal hierarchy, they do not have the same leeway to delegate interpretive authority. Redish also argues that there is no way to limit Sager's logic to constitutional cases, as the federal supremacy interest would seemingly require federal courts to police state courts on all issues of federal law because " $[\mathrm{t}]$ he supremacy clause, it should be recalled, is not limited in its dictates to matters of constitutional law, much less of constitutional right." Id. at 148. This argument is directly addressed in this Comment by noting that the Supremacy Clause does make an essential distinction between constitutional and federal law. See, e.g., supra Part III.A. Finally, Redish responds to Sager's reliance on the Article III salary and tenure provision, which is not addressed in this Comment. Id. at 149.

${ }^{139}$ See Ratner, supra note 8, at 185-86 ("A state court decision upholding a right claimed under a federal statute does not challenge the supremacy of federal law.").

${ }^{140}$ Even if gaps exist, they are not necessarily fatal to a theory that would place some limits on congressional jurisdiction-stripping power. First, while "tradition treats the constitutional views of members of the first Congress as entitled to great respect," the Judiciary Act is merely persuasive evidence of the constitutional framers' intent, and it is possible that those enacting the Act misunderstood the import of particular phrases of constitutional text. Meltzer, supra note 34, at 1610; see also Amar, supra note 10 , at 1541 ("The political safeguards principle is a constant reminder that even the 
It also comports with the text of Article III, which gives Congress only the power to make exceptions; it "implies a minor deviation from a surviving norm," ${ }^{142}$ not an exception that swallows the rule. Professor Sager was correct in arguing that "the essential function claim is strongest when narrowed to Supreme Court review of state court decisions that repudiate federal constitutional claims of right," he proffered a more expansive argument himself. And the evidence supporting the framers' intention to ensure that an independent federal judiciary preserve federal supremacy remains persuasive. ${ }^{144}$

There is also evidence tending to establish a direct connection between the text of the Supremacy Clause and Article III, implying that the framers intended the federal judiciary to be the final arbiters of constitutional law. It is no accident that there is a striking similarity between the text of the Supremacy Clause, which makes supreme " $[\mathrm{t}] \mathrm{his}$ Constitution, and the Laws of the United States which shall be made in Pursuance thereof; and all Treaties made, or which shall be made, under the Authority of the United States, ${ }^{, 155}$ and the first line of Article III, Section 2, which says that the federal judicial power shall extend to all cases arising under "this Constitution, the Laws of the United States, and Treaties made, or which shall be made, under their authority."146 The initial draft of the Supremacy Clause included a specified role for the federal judiciary and referred only to violations of the Constitution, not federal law, stating: "All laws of a particular state, repugnant hereto, shall be void, and in the decision thereon, which shall be

first Congress may have misunderstood the Constitution."). Further, the legislators in 1789 "may have been re-fighting old battles about the Constitution" by interpreting it to best fit their political views. Meltzer, supra note 34, at 1611. However, the First Judiciary Act certainly is persuasive evidence, and in fact strongly supports a view of mandatory federal court review over issues that implicate Constitutional supremacy issues. See also Amar, supra note 10, at 1529-31 (arguing that section 25 of the Judiciary Act could merely be interpreted as enacting a construction of "arising under" rather than making a jurisdictional exception, and that section 25 was merely a way of packaging the pleading of a constitutional right and enforced no real limitation on appellate power).

${ }^{141}$ Gunther, supra note 8, at 907 (arguing against the "essential functions" thesis because of its uniformity and separation-of-powers bases).

${ }^{142}$ Sager, supra note 4, at 44; see also Ratner, supra note 8, at 168-69 (“[A]n exception cannot nullify the rule or description that it limits.").

${ }^{143}$ Sager, supra note 4 , at 44.

${ }^{144}$ See Clinton, supra note 8, at 758; Sager, supra note 4, at 45 ("The Constitution itself and events at the Constitutional Convention show that those who crafted the document intended that the Supreme Court should supervise the states.").

${ }^{145}$ U.S. CONST. art. VI, cl. 2.

${ }^{146}$ Id. art. III, § 2, cl. 1; see also supra note 31 . 
vested in the supreme judiciary, all incidents without which the general principles cannot be satisfied shall be considered, as involved in the general principle." ${ }^{147}$ Though this language was altered, Professor Sager points out that the Constitutional Convention delegates continued to recognize "the crucial link between national supremacy and the appellate jurisdiction of the Supreme Court" by harmonizing Supreme Court authority in the Article III text with the final version of the Supremacy Clause. ${ }^{148}$ Professor Ratner also identified the "concurrent development of the supremacy clause" as giving added significance to Article III jurisdiction because the motion adding judicial power over treaties to Article III referred to "conform[ing] to a preceding amendment in another place"-that is, the Supremacy Clause. ${ }^{149}$ This occurred immediately after the judicial power was extended to review cases arising under "this Constitution,"150 which illustrates that the judicial power under Article III was sculpted in concurrence with the Supremacy Clause and provides evidence that such power was intended to both implement and be limited by it. As Professor Amar argues, "[ $\mathrm{t}]$ he supremacy clause would oblige state judges to follow the supreme law of the Constitution at the trial level; appellate review by Article III judges would assure faithful and accurate discharge of this obligation." James Madison to Thomas Jefferson, in which Madison explained:

[T] he General Convention regarded a provision within the Constitution for deciding in a peaceable [and] regular mode all cases arising in the course of its operation, as essential to an adequate System of Gov[ernment $]. . . .[\mathrm{I}] \mathrm{t}$ intended the Authority vested in the Judicial Department as a final resort in relation to the States, for cases resulting to it in the exercise of its functions .... [T] his intention is expressed by the articles declaring that the federal Constitution and laws shall be the

${ }^{147}$ Sager, supra note 4, at 48-49 (quoting 2 Farrand's RECORDS, supra note 66, at 144 (Committee of Detail, IV)).

${ }^{148}$ See id. at 49 ("Article III was thus tailored to facilitate Supreme Court enforcement of the supremacy clause.").

${ }^{149}$ Ratner, supra note 8, at 164-65 (quoting 2 Farrand's RECORDS, supra note 66, at 431 (Aug. 27))

${ }^{150}$ Id. ("[T] aken together, these resolutions evidence the Convention's purpose to make the Supreme Court the principal instrumentality for implementing the supremacy clause.").

${ }^{151}$ Amar, supra note 44, at 249. 
supreme law of the land, and that the Judicial Power of the [United

States] shall extend to all cases arising under them ....

This provides further support for the theory that the Supremacy Clause was intended to ensure federal court jurisdiction over constitutional cases as a last resort.

It is important to note that a constitutional supremacy theory of federal court jurisdiction does not necessarily require that the Supreme Court be the court to ensure constitutional supremacy. While many scholars make persuasive arguments that the Court was intended to serve this purpose ${ }^{153}$ there is evidence that Congress could designate inferior federal courts as the final arbiters of particular issues and still serve the demands of constitutional supremacy. ${ }^{154} \mathrm{Re}-$ gardless of how that particular argument is ultimately decided, Supreme Court precedent upholds the importance of having some federal forum to vindicate the Supremacy Clause. ${ }^{155}$

\section{Applicability to Current and Future Proposals}

The application of a constitutional supremacy theory to the two recently proposed congressional jurisdiction-stripping bills would be positively received by those who favor federal review of the important constitutional issues involved. The Marriage Protection Act seeks to evade federal court review of the scope of the Full Faith and Credit Clause of Article IV and the Equal Protection and Due Process Clauses of the Fourteenth Amendment. Thus, under the theory posed here, any challenges to a state's nonrecognition of a same-sex marriage sanctioned by another state would have the chance to be reviewed, ultimately, by the Supreme Court. Because the Full Faith and Credit Clause of the Constitution is, by its very nature, a rule intended to create uniformity between the states and a rule which states have differing interests in construing under particular interpretations, it is all the

${ }^{152} I d$. at 249-50 (quoting Letter from James Madison to Thomas Jefferson (June 27, 1823), in 4 The RECORDS OF THE CONSTITUTIONAL CONVENTION OF 1787, at 83-84 (Max Farrand ed., 1937) (alterations in original).

${ }^{153}$ See, e.g., Ratner, supra note 8, at 160-67 (discussing the structural, historical, and precedential bases for necessary Supreme Court review of cases implicating the Supremacy Clause).

154 See Amar, supra note 44, at 222, 262 (noting the structural parity between all federal judicial officers and that the 1789 Judiciary Act had a $\$ 2000$ minimum-amountin-controversy requirement for Supreme Court review of federal circuit court civil cases, and did not allow Supreme Court review of federal circuit court criminal cases at all).

${ }^{155}$ See supra notes 106-10 and accompanying text (discussing the Court's jurisprudence in the Young line of cases). 
more important to secure a federal forum to interpret the supreme law of the Constitution. Similarly, the sheer national importance of interpretation of the Establishment Clause weighs against allowing state courts to have the last word with regard to the "Pledge Protection Act." Regardless of how the Supreme Court would actually rule in these cases, recognizing an irreducible federal court power to review constitutional cases would prevent such a result, maintaining flexibility for implementation of federalist interests while preserving ultimate vindication of nationalist principles.

Establishing that, at a minimum, federal court review of state constitutional rulings is mandatory would also have broader implications in discouraging ill-motivated jurisdiction-stripping proposals in general. Because the purpose of many of these bills is to overturn or evade Supreme Court rulings, the heart would be cut out of these proposals, and congressional control of federal jurisdiction, while still extensive, would be essentially limited to dividing classes of cases between the courts for procedural reasons. Though Congress could still limit original litigation of substantive constitutional legal issues to state courts, the political value of such a limitation would be greatly diminished because the Supreme Court would still have the ability to speak the last word.

\section{CONCLUSION}

A theory of constitutional supremacy as a limiting factor on Congress's jurisdiction-stripping power is a strong starting point for those who seek to balance the nationalist and federalist concerns at the heart of this debate. It recognizes that the Constitution's framers believed in the state courts' competency to hear issues of federal and constitutional law, but that they also believed a federal forum for appeals was necessary to uphold the principles embodied in the Supremacy Clause. When balancing the two concerns, it is evident that even if the Supremacy Clause is not violated when Congress voluntarily relinquishes its interest in federal court interpretation of its laws in a nonconstitutional sense, the Supremacy Clause is violated when Congress attempts to remove federal court appellate review of constitutional issues. Recognizing this consequence would prevent some of the more egregious attempts by Congress to reverse or evade Supreme Court constitutional precedents by curtailing jurisdiction, but allow Congress to use the state courts as full participants in the adjudication of federal and constitutional law, as the Madisonian Compromise intended. 